ISSN 1029-8940 (Print)

ISSN 2524-230X (Online)

УДК 577.355:582.663:58.032.3

Поступила в редакцию 04.05.2021

https://doi.org/10.29235/1029-8940-2021-66-3-282-294

Received 04.05.2021

\author{
Л. Ф. Кабашникова ${ }^{1}$, И. Н. Доманская ${ }^{1}$, Т. С. Пилипович ${ }^{1}$, Л. В. Пашкевич ${ }^{1}$, \\ А. В. Мартысюк ${ }^{1}$, С. М. Мотылева ${ }^{2}$, М. С. Гинс ${ }^{3}$, Н. В. Тетянников ${ }^{2}$ \\ ${ }^{1}$ Институт биофизики и клеточной инженерии НАН Беларуси, Минск, Республика Беларусь \\ ${ }^{2}$ Федеральный научный селекиионно-технологический центр садоводства и питомниководства, \\ Москва, Российская Федераиия \\ ${ }^{3}$ Федеральный научный центр овощеводства, Москва, Российская Федераиия

\section{СОДЕРЖАНИЕ ФОТОСИНТЕТИЧЕСКИХ ПИГМЕНТОВ И ПАРАМЕТРЫ ОКИСЛИТЕЛЬНОГО СТРЕССА В ЛИСТЬЯХ АМАРАНТА ПРИ НАРАСТАЮЩЕМ ВОДНОМ ДЕФИЦИТЕ}

\begin{abstract}
Аннотация. Изучена динамика содержания фотосинтетических пигментов и параметров окислительного стресса при нарастающем водном дефиците в листьях 40-дневных растений двух видов амаранта - Amaranthus paniculatus L. (сорт Рубин) и Amaranthus caudatus L. (сорт Чырвоны аксамит), выращенных в горшечной культуре. Обнаружены видовые особенности развития водного дефицита в листьях амаранта: у растений амаранта Amaranthus paniculatus L. уже через 4 дня почвенной засухи отмечалось более сильное развитие водного дефицита (WD), чем у Amaranthus caudatus L., а через 8 дней WD у двух видов возрастал до 73,7 и 55,7 \% соответственно. При умеренной засухе количество фотосинтетических пигментов (хлорофилла (Хл) и каротиноидов) в пересчете на сухую массу листа увеличивалось у двух видов амаранта, но через 8 дней почвенной засухи содержание Хл $(a+b)$ было снижено в 2,0-2,1 раза, а каротиноидов - в 1,8-1,9 раза относительно физиологического уровня. В результате 4 -дневной почвенной засухи в листьях Amaranthus paniculatus L. происходило существенное снижение содержания активных форм кислорода (АФК) и активности перекисного окисления липидов (ПОЛ), тогда как у Amaranthus caudatus L. наблюдалось повышение уровней АФК и ПОЛ. При возрастании давления стрессового фактора в листьях амаранта двух изученных видов отмечалось снижение содержания АФК и активности ПОЛ относительно физиологических значений. Предполагается, что на разных этапах почвенной засухи в листьях изученных видов амаранта имеются различия в механизмах генерации АФК и процессах ПОЛ.

Ключевые слова: водный дефицит, фотосинтетические пигменты, активные формы кислорода, перекисное окисление липидов, амарант, Amaranthus paniculatus L., Amaranthus caudatus L.

Для цитирования: Содержание фотосинтетических пигментов и параметры окислительного стресса в листьях амаранта при нарастающем водном дефиците / Л. Ф. Кабашникова [и др.] // Вес. Нац. акад. навук Беларусі. Сер. біял. навук. - 2021. - Т. 66, № 3. - С. 282-294. https://doi.org/10.29235/1029-8940-2021-66-3-282-294
\end{abstract}

Luidmila F. Kabashnikova ${ }^{1}$, Irina N. Domanskaya ${ }^{1}$, Tatsiana S. Pilipovich ${ }^{1}$, Liubou V. Pashkevich', Hanna V. Martysiuk ${ }^{1}$, Svetlana M. Motyleva ${ }^{2}$, Murat S. Gins ${ }^{3}$, Nikolay V. Tetyannikov ${ }^{2}$

${ }^{1}$ Institute of Biophysics and Cell Engineering of the National Academy of Sciences of Belarus, Minsk, Republic of Belarus ${ }^{2}$ Federal Horticultural Research Center for Breeding, Agrotechnology and Nursery, Moscow, Russian Federation ${ }^{3}$ Federal Scientific Center of Vegetable Growing, Moscow, Russian Federation

\title{
PHOTOSYNTHETIC PIGMENTS CONTENT AND PARAMETERS OF OXIDATIVE STRESS IN THE AMARANTH SPECIES WITH INCREASING WATER DEFICIENCY
}

Abstract. The dynamics of the photosynthetic pigments content and parameters of oxidative stress with an increasing water deficit in the leaves of 40-days-old plants of two amaranth species - Amaranthus paniculatus L. (cv. Rubin) and Amaranthus caudatus L. (cv. Chyrvony aksamit), grown in a pot culture, was studied. Specific features of the development of water deficiency in amaranth leaves were revealed: amaranth plants Amaranthus paniculatus L. showed a stronger development of water deficit in leaves than Amaranthus caudatus L. after 4-days soil drought, which after 8 days increased in two species to 73.7 and $55.7 \%$, respectively. Under moderate drought, the amount of photosynthetic pigments (chlorophyll (Chl) and carotenoids) based on dry leaf weight increased in two amaranth species, but after 8 days of soil drought, the content of Chl $(a+b)$ was reduced by 2.0-2.1 times, and carotenoids - 1.8-1.9 times relative to the physiological level. As a result of a 4-days soil drought in the leaves of Amaranthus paniculatus L., there was a significant decrease in the content of reactive oxygen species (ROS) and the activity of lipid peroxidation (LPO), while in Amaranthus caudatus L. an increase in the levels of ROS and LPO was observed. With an increase in the pressure of the stress factor in the leaves of amaranth of the two studied species, a decrease in the ROS content and LPO activity relative to physiological values was revealed. A conclusion 
was made about the different mechanisms of ROS generation and the flow of LPO processes at different stages of soil drought in the leaves of different amaranth species.

Keywords: water deficit, photosynthetic pigments, reactive oxygen species, lipid peroxidation, amaranth, Amaranthus paniculatus L., Amaranthus caudatus L.

For citation: Kabashnikova L. F., Domanskaya I. N., Pilipovich T. S., Pashkevich L. V., Martysiuk H. V., Motyleva S. M., Gins M. S., Tetyannikov N. V. Photosynthetic pigments content and parameters of oxidative stress in the amaranth species with increasing water deficiency. Vestsi Natsyyanal'nai akademii navuk Belarusi. Seryya biyalagichnykh navuk = Proceedings of the National Academy of Sciences of Belarus. Biological series, 2021, vol. 66, no. 3, pp. 282-294 (in Russian). https://doi. org/10.29235/1029-8940-2021-66-3-282-294

Введение. Для растительных организмов вода является физическим и биохимическим компонентом, поэтому стратегии ее эффективного использования и повышения устойчивости культурных растений к засухе имеют первостепенное значение. В течение своего жизненного цикла растения могут испытывать частые периоды дефицита воды даже за пределами засушливых и полузасушливых районов. Некоторые различия в росте и выживании растений можно отнести скорее к разной способности поглощать, транспортировать и сохранять воду, чем к различиям в метаболизме [1]. Ранние реакции растений на водный стресс можно рассматривать как первую линию защиты, позволяющую выживать в течение непродолжительного времени. Чтобы пережить более длительные стрессовые периоды, растения должны пройти процесс акклиматизации, что в свою очередь приводит к изменениям метаболизма и/или структуры, опосредованным изменениями в регуляции экспрессии генов. Степень повреждения растительной клетки в результате действия засухи зависит от вида, сорта растения, продолжительности времени обезвоживания, стрессоустойчивости культуры.

Род Amaranthus включает много ценных зерновых и овощных культур [2], которые по типу фотосинтеза относятся к С4-растениям. Зерна и листья растений амаранта богаты питательными веществами и минералами $[3,4]$, которые не только используются в пищу, но и служат источником сырья для фармацевтического и биотехнологического производства биологически активных субстанций. C4-растения развивались 50-60 млн лет назад, когда температура воздуха была выше на $8-10{ }^{\circ} \mathrm{C}$, а концентрация $\mathrm{CO}_{2}$ в атмосфере была ниже, чем сейчас. Однако и в настоящее время эти растения, находясь в засушливых и полузасушливых условиях [5], относятся к числу наиболее продуктивных видов. Около 7500 видов С4-растений обеспечивают $23 \%$ первичной продуктивности в наземной биосфере [6] и составляют основные продовольственные и кормовые ресурсы во всем мире. Кроме того, рост населения планеты, а также прогнозируемое уменьшение доступности воды в нескольких географических регионах в связи с изменением климата предполагает увеличение использования С4-растений в сельском хозяйстве [7]. С4-растения могут сохранять фотосинтетическую активность [8] и рост корней и побегов [9] при потенциале воды, который ингибирует большинство С3-растений, имеют более высокую устойчивость устьиц и эффективнее используют воду (water use efficiencies, WUE), чем их C3-аналоги. Тем не менее все еще остается предметом спора вопрос, являются ли С4-растения более устойчивыми к недостаточному водообеспечению [10].

Известно, что стресс в результате засухи приводит к накоплению активных форм кислорода (АФК), которые могут инициировать деструктивные окислительные процессы, такие как перекисное окисление липидов (ПОЛ), выцветание хлорофилла (Хл) и беталаина, а также окисление белка [11]. Растения развили как ферментативные, так и неферментативные защитные системы для удаления и детоксикации АФК, что привело к формированию антиоксидантной защитной системы [12]. В результате засухи происходит активное накопление ряда соединений (например, пролина, $\alpha$-токоферола и полифенолов), которые защищают растения от окислительного повреждения и позволяют сохранять положительное тургорное давление, что является обязательным условием для поддержания апертуры устьиц и газообмена [12]. Кроме того, неферментативные антиоксиданты, такие как пигменты листьев, аскорбиновая кислота, каротиноиды, фенолы и флавоноиды, играют защитную роль во избежание образования АФК [13]. Согласно заключению, представленному в работе [14], существует три основных типа реакции растений на стресс, вызванный засухой: предотвращение потери воды (например, осмотическая коррек- 
тировка); защита клеточных компонентов (например, качественные и количественные изменения пигментов) и восстановление от окислительного повреждения (например, антиоксидантные системы).

В ряде работ, выполненных на растениях амаранта в качестве объектов исследования, были изучены некоторые антиоксидантные показатели высокоурожайных сортов [14-17]. Обнаружено, что в растениях A. tricolor стресс в условиях засухи приводил к снижению общей биомассы растений, удельной площади листьев, относительного содержания воды $(R W C)$, фотосинтетических пигментов (Хл $a$, Хл $b$, Хл $(a+b))$ и растворимого белка, но вызывал увеличение содержания малонового диальдегида (МДА), $\mathrm{H}_{2} \mathrm{O}_{2}$, пролина, каротиноидов, аскорбиновой кислоты, полифенолов, флавоноидов и общей антиоксидантной активности [18]. Изученные параметры, дифференциальные по отношению к сортам и степени стрессового воздействия засухи, были предложены для использования в новых программах создания сортов и в разрабатываемых программах их размножения. Положительно значимые корреляции между МДА, $\mathrm{H}_{2} \mathrm{O}_{2}$, осмопротекторами и неферментативными антиоксидантами (пролин, фенолы, флавоноиды, общая антиоксидантная способность) позволили авторам предположить, что эти соединения играют жизненно важную роль в детоксикации АФК в растениях A.tricolor.

В Беларуси внедрение культуры амаранта ограничено недостаточными знаниями о ее экологии и физиологии, что препятствует широкому распространению этой ценной овощной культуры, особенно в северных регионах с низкой весенней температурой [19]. Проведенный анализ научной литературы свидетельствует об актуальности исследований, направленных на изучение окислительного статуса растений амаранта путем сравнения сортов разных видов в условиях почвенной засухи, что имеет важное значение для выявления видовых особенностей развития окислительного стресса и маркеров, определяющих засухоустойчивость разных генотипов амаранта.

Цель данного исследования - изучение особенностей развития окислительного стресса в листьях двух видов амаранта при водном дефиците, вызванном почвенной засухой.

Объекты и методы исследования. В исследованиях использовали растения амаранта двух видов - Amaranthus paniculatus L. (сорт Рубин) и Amaranthus caudatus L. (сорт Чырвоны аксамит). Вид Amaranthus paniculatus L. (сорт Рубин) декоративного назначения, районирован в Республике Беларусь в 2002 г., имеет ветвистый округлый стебель высотой до 2 м, ярко-красной или зеленой окраски [20]. Листья яйцевидно-ромбические, заостренные, шершавые, расположены на длинных черешках, красно-зеленого цвета. Мелкие цветки собраны в кисти, образующие в верхней части крупную (длиной до 70-80 см) ветвистую прямостоячую, иногда с наклонной верхушкой, ярко-красную, бордовую или зеленую метелку. Семена очень мелкие, округлые, блестящие, окраска их может быть черной, масса 1000 семян составляет 0,5-0,9 г. Вид Amaranthus caudatus L. (сорт Чырвоны аксамит) декоративного назначения, создан в ГНУ «Центральный ботанический сад НАН Беларуси», районирован в 2020 г., имеет стебель и листья зеленого цвета и соцветия красного цвета, высота растений - 130-140 см, масса 1000 семян $-0,6$ г.

Растения амаранта выращивали в горшечной культуре на торфо-песчаном субстрате (4:1) до 40 -дневного возраста в условиях климатокамеры, при температуре $22-24{ }^{\circ} \mathrm{C}$, на полихроматическом белом свету (120 мкM квантов $\left.\mathrm{m}^{-2} \cdot \mathrm{c}^{-1}\right)$ при 14-часовом фотопериоде. Затем растения в опыте переставали поливать в течение 4 или 8 дней до появления первых признаков увядания. Контрольные растения поливали каждые 4 дня до увлажнения почвы. Для анализа использовали листья среднего яруса 44- и 48-дневных растений амаранта.

Параметры водного обмена в листьях амаранта определяли по содержанию сухого вещества $(D M C)$, относительному содержанию воды $(R W C)$ и водному дефициту $(W D)$, которые вычисляли с использованием параметра $T W$ (биомасса листа при достижении его клетками состояния полного тургора в результате 24-часовой инкубации в дистиллированной воде) по формулам, приведенным в работе [21]. Для этого отбирали три навески из средней пробы измельченных листьев, взвешивали, затем высушивали до постоянного веса при $105{ }^{\circ} \mathrm{C}$. Сырую $(F W)$ и сухую $(D W)$ биомассу определяли на весах Ohaus AR2140 (Япония).

$D M C, R W C$ и $W D$ вычисляли по следующим формулам: 


$$
\begin{gathered}
D M C=D W / F W \cdot 100 \%, \\
R W C=(F W-D W) /(T W-D W) \cdot 100 \%, \\
W D=(T W-F W) / T W \cdot 100 \% .
\end{gathered}
$$

Для экстракции пигментов использовали высечки из мезофилла листа. Экстракцию Хл и каротиноидов производили в трехкратной биологической повторности, используя 99,5 \%-ный ацетон. Количество пигментов в экстрактах определяли по спектрам поглощения на спектрофотометре Shimadzu UV-2401PC (Shimadzu, Япония). Содержание пигментов рассчитывали по формулам, предложенным в работе [22]:

$$
\begin{gathered}
C_{a}=9,784 E_{662}-0,99 E_{644}, \\
C_{b}=21,426 E_{644}-4,65 E_{662}, \\
C_{c a r}=4,695 E_{440,5}-0,268\left(C_{a}+C_{b}\right),
\end{gathered}
$$

где $C_{a}$ - концентрация Хл $a$, мкг/мл; $C_{b}$ - концентрация Хл $b$, мкг/мл; $C_{c a r}-$ концентрация каротиноидов, мкг/мл; $E$ - экстинкция при соответствующей длине волны.

Содержание фотосинтетических пигментов рассчитывали на 1 г сухой массы листа.

Для анализа активности ПОЛ определяли количество активных продуктов, взаимодействующих с тиобарбитуровой кислотой (ТБК) по методу, приведенному в работе [23]. Растительный материал гомогенезировали в 5 мМ фосфатном буфере (pH 7,2). К гомогенату добавляли равный объем 0,5 \%-ной ТБК в $20 \%$-ной трихлоруксусной кислоте. Полученные образцы нагревали на кипящей бане в течение 20 мин, охлаждали и центрифугировали при 3000 об/мин. Супернатант измеряли фотометрически при 532 нм. Количество МДА рассчитывали с учетом миллимолярного коэффициента экстинкции комплекса МДА-ТБК, который с поправкой на неспецифическое поглощение при $\lambda=600 \mathrm{Hм}\left(1,5 \mathrm{M}^{-1} \cdot \mathrm{cm}^{-1}\right)$ составил $155 \cdot 10^{5} \mathrm{M}^{-1} \cdot \mathrm{cm}^{-1}$ [24].

Общий уровень АФК оценивали с помощью флуоресцентного теста, в основе которого лежит образование дихлорфлуоресцеина (ДХФ) из нефлуоресцирующего дихлорфлуоресцеиндиацетата (ДХФДА) в экстрактах листьев. Навески листьев по 0,25 г гомогенизовали в 2 мл $0,2 \mathrm{H} \mathrm{HClO}_{4}$. Гомогенат центрифугировали в течение 10 мин при $13000 \mathrm{~g}$. Для нейтрализации кислотности к 500 мкл суспензии добавляли 37-38 мкл 4 М КОН (конечное значение $\mathrm{pH}$ - 7,5$8,0)$ и центрифугировали 5 мин при 13000 g. Для определения АФК к 950 мкл 0,15 М ТрисHCL буфера (pH 7,5) последовательно добавляли 25 мкл нейтрализованного супернатанта и 25 мкл 0,15 мМ раствора ДХФДА. Контролем служит проба, состоящая из 975 мкл 0,15 М Tрис-HCL буфера и 25 мкл 0,15 мМ ДХФДА. Все пробы инкубировали в течение 20 мин в термостате при $37^{\circ} \mathrm{C}$ в темноте. Уровень АФК определяли по калибровочной кривой, регистрируя флуоресценцию ДХФ $\left(\lambda_{\text {возо }}=496, \lambda_{\text {рег }}=524\right)$ с помощью спектрофлуориметра «СОЛАР СМ 2203» («СОЛАР», Беларусь) [25].

Для статистической обработки данных использовали стандартные пакеты программ Excel 2016, SigmaPlot 12.0 и статистические методы, принятые в области биологических исследований [26]. Приведены средние значения из трех независимых экспериментов и их стандартные ошибки. Различия по сравнению с контролем считали достоверными при уровне значимости $p \leq 0,05$.

Результаты и их обсуждение. Параметры водного обмена в листьях амаранта через 4 и 8 дней почвенной засухи представлены в табл. 1, 2. Обнаружено, что у вида Amaranthus paniculatus L. (сорт Рубин) недостаток влаги вызывал снижение $R W C$ в листьях на 33,1 \% через 4 дня почвенной засухи, а через 8 дней - на 68,7 \% по сравнению с контролем. Соответственно, в условиях засухи в листьях Amaranthus paniculatus L. водный дефицит через 4 дня возрастал в 2,6 раза, через 8 дней - в 5,2 раза, а DMC увеличилось в 1,6 и 4,3 раза соответственно. Для Amaranthus caudatus L. (сорт Чырвоны аксамит) признаки обезвоживания листьев через 4 дня засухи были слабо выражены, а через 8 дней параметр $R W C$ снизился на 36,6 \% относительно контроля, что вызывало увеличение показателей $W D$ и $D M C$ в 2,1 и 2,4 раза соответственно. 
Т а б л и ц а 1. Параметры водного обмена в листьях двух видов амаранта (Amaranthus caudatus L. и Amaranthus paniculatus L.) через 4 дня почвенной засухи

$\mathrm{T}$ a b 1 e 1. Parameters of water deficit in leaves of two amaranth species (Amaranthus caudatus $\mathbf{L}$. and Amaranthus paniculatus L.) under 4-days of soil drought

\begin{tabular}{|l|c|c|c|c|}
\hline \multirow{2}{*}{ Параметр } & \multicolumn{2}{|c|}{ Amaranthus caudatus L. (сорт Чырвоны аксамит) } & \multicolumn{2}{|c|}{ Amaranthus paniculatus L. (сорт Рубин) } \\
\cline { 1 - 5 } & Контроль & Засуха & Контроль & Засуха \\
\hline$R W C, \%$ & $71,9 \pm 6,8$ & $66,0 \pm 5,8$ & $78,2 \pm 0,7$ & $45,1 \pm 3,5^{*}$ \\
\hline$W D, \%$ & $25,4 \pm 1,5$ & $30,1 \pm 2,7^{*}$ & $18,1 \pm 1,3$ & $46,2 \pm 2,7^{*}$ \\
\hline$D M C, \%$ & $12,4 \pm 0,9$ & $16,3 \pm 1,1$ & $13,5 \pm 0,9$ & $22,1 \pm 1,6^{*}$ \\
\hline
\end{tabular}

П р и м е ч а н и е. *-достоверность различий с соответствующим контролем при $p<0,05$. То же в табл. 2 и на рис. $1-3$.

Т а б л и ц а 2. Параметры водного обмена в листьях двух видов амаранта (Amaranthus caudatus L. и Amaranthus paniculatus L.) через 8 дней почвенной засухи

$\mathrm{T}$ a b 1 e 2. Parameters of water deficit in leaves of two amaranth species (Amaranthus caudatus L. and Amaranthus paniculatus ) under 8-days of soil drought

\begin{tabular}{|l|c|c|c|c|}
\hline \multirow{2}{*}{ Параметр } & \multicolumn{2}{|c|}{ Amaranthus caudatus L. (сорт Чырвоны аксамит) } & \multicolumn{2}{|c|}{ Amaranthus paniculatus L. (сорт Рубин) } \\
\cline { 1 - 5 } & Контроль & Засуха & Контроль & Засуха \\
\hline$R W C, \%$ & $70,4 \pm 5,7$ & $33,8 \pm 2,1^{*}$ & $84,4 \pm 6,4$ & $15,7 \pm 0,8^{*}$ \\
\hline$W D, \%$ & $26,4 \pm 1,4$ & $55,7 \pm 4,2^{*}$ & $14,1 \pm 0,8$ & $73,7 \pm 5,6^{*}$ \\
\hline$D M C, \%$ & $14,6 \pm 0,9$ & $35,7 \pm 2,1^{*}$ & $11,2 \pm 0,5$ & $47,8 \pm 2,0^{*}$ \\
\hline
\end{tabular}

После 4-дневной почвенной засухи количество фотосинтетических пигментов (Хл и каротиноидов) в пересчете на сухую массу листа увеличивалось у двух видов амаранта, причем наиболее существенно у вида Amaranthus paniculatus L. (сорт Рубин) (рис. 1, a). При этом соотношение Хл $a /$ Хл $b$ в листьях Amaranthus caudatus L. несколько возрастало относительно контроля, а в листьях Amaranthus paniculatus L. - уменьшалось на фоне сниженного соотношения Хл $(a+b) /$ каротиноиды у двух изученных видов. Через 8 дней в физиологических условиях наблюдалось онтогенетическое увеличение содержания фотосинтетических пигментов в листьях двух видов амаранта, причем у вида Amaranthus paniculatus L. более значительное, чем у вида Amaranthus caudatus L. В условиях засухи в этот период в листьях двух видов амаранта происходило снижение содержания Хл $(a+b)$ в 2,0-2,1 раза относительно контроля (рис. $1, b)$. Содержание фракций отдельных пигментов (Хл $a$ и Хл $b$ ) изменялось аналогичным образом, в результате чего соотношение Хл $a /$ Хл $b$ в опыте и контроле практически не изменялось. При усилении почвенной засухи общее количество каротиноидов в листьях амаранта двух изученных видов снижалось в 1,8-1,9 раза по сравнению с контролем, без существенного изменения соотношения Хл $(a+b) /$ каротиноиды в листьях. В целом, полученные результаты свидетельствуют о негативном влиянии засухи на накопление основных фотосинтетических пигментов (Хл и каротиноидов) в листьях двух видов амаранта. Следует отметить, что величина снижения содержания фотосинтетических пигментов (Хл $(a+b)$ и каротиноидов) для Amaranthus paniculatus L. и Amaranthus caudatus L. оказалась практически одинаковой, несмотря на разную степень водного дефицита в листьях этих видов.

Как известно, процесс фотосинтеза в растительных организмах сопровождается образованием молекулярного кислорода $\left(\mathrm{O}_{2}\right)$, что необходимого для нормального функционирования биологических систем. Однако $\mathrm{O}_{2}$ несет потенциальную угрозу развития в клетках фотодеструктивных процессов, связанных с образованием АФК, таких как молекулярный синглетный кислород $\left({ }^{1} \mathrm{O}_{2}\right)$, супероксидный анион-радикал $\left(\mathrm{O}_{2}^{--}\right)$, пероксид водорода $\left(\mathrm{H}_{2} \mathrm{O}_{2}\right)$, гидроксильный радикал $\left({ }^{\circ} \mathrm{OH}\right)$,) и др. [27]. В процессе жизнедеятельности растений ликвидация АФК происходит за счет защитной антиоксидантной системы, включающей низкомолекулярные антиоксиданты, антиоксидантные ферменты и защитные белки. В стрессовых условиях образование АФК усиливается, что в ряде случаев приводит к усилению деструктивных процессов в растениях и даже к гибели 

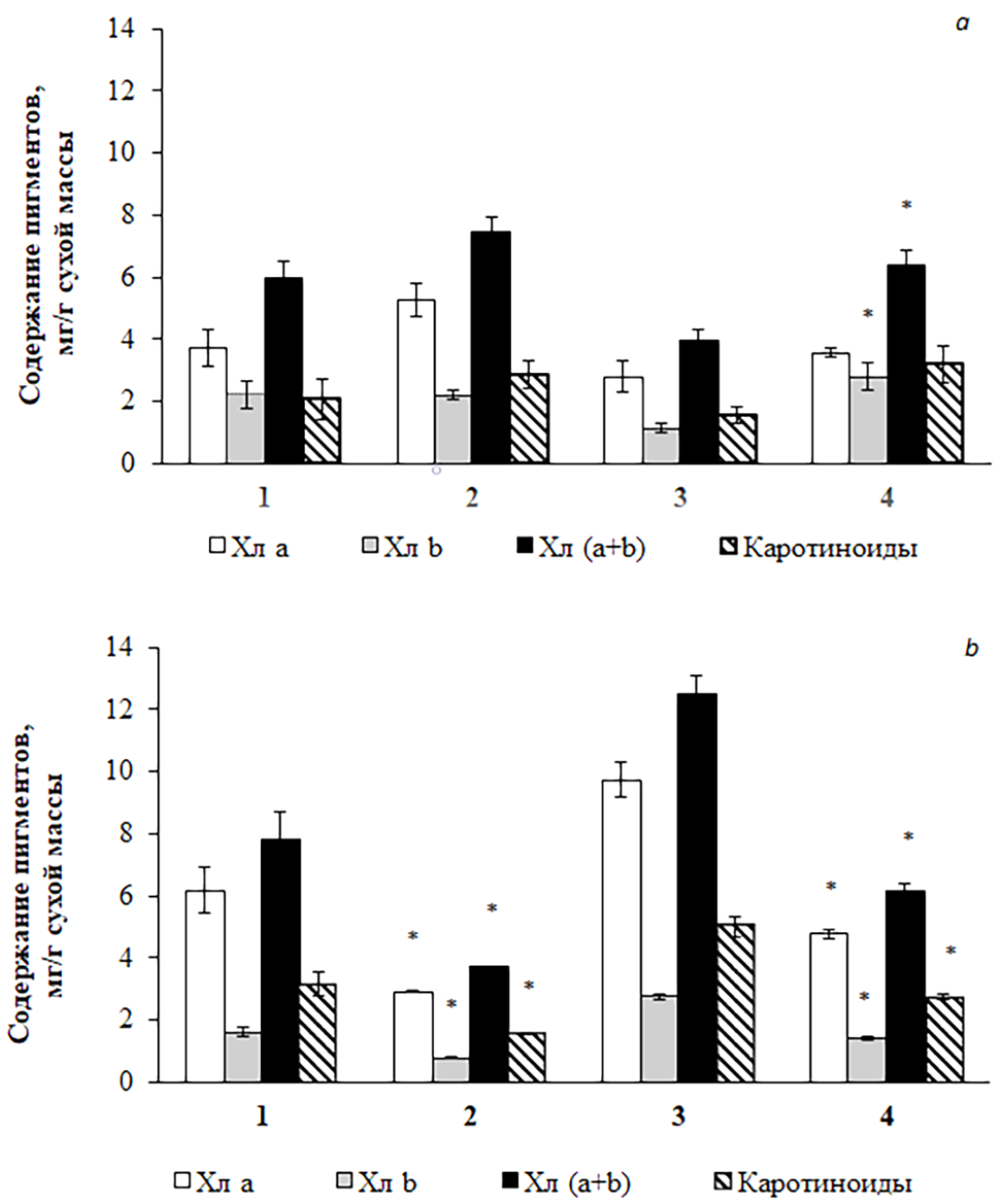

Рис. 1. Влияние 4-дневной $(a)$ и 8-дневной $(b)$ почвенной засухи на содержание фотосинтетических пигментов в листьях Amaranthus caudatus L., сорт Чырвоны аксамит (1 - контроль, 2 - засуха) и Amaranthus paniculatus L., сорт Рубин (3 - контроль, 4 - засуха)

Fig. 1. Effect of 4-days (a) and 8-days (b) soil drought on photosynthetic pigments content in amaranth leaves of species Amaranthus caudatus L., Chyrvony aksamit (1 - control, 2 - drought) and Amaranthus paniculatus L., Rubin (3- control, 4- drought)

наиболее чувствительных видов. В частности, засуха, как и другие абиотические факторы, приводит к многократному увеличению в клетках уровня АФК, таких как $\mathrm{O}_{2}^{-{ }^{-}}, \mathrm{H}_{2} \mathrm{O}_{2}$ и ${ }^{\cdot} \mathrm{OH}$. Повышение уровня АФК при стрессе действует как сигнал тревоги, который запускает акклиматизационные/защитные реакции посредством определенных путей передачи сигналов, которые включают $\mathrm{H}_{2} \mathrm{O}_{2}$ в качестве вторичного мессенджера. Передача сигналов АФК в условиях засухи связана с сигнальными путями, в которых участвуют абсцизовая кислота (АБК), ионы $\mathrm{Ca}^{2+}$ и сахара, и вызывает как активацию, так и подавление АБК-зависимых сигнальных путей [28]. В литературе накоплены сведения об участии различных АФК в трансдукции сигналов, приводящих к активации ферментов-антиоксидантов и экспрессии их генов [27].

Проведен анализ общего содержания АФК как показателя окислительного потенциала в клетках мезофилла листа у двух видов амаранта - Amaranthus paniculatus L. (сорт Рубин) и Amaranthus caudatus L. (сорт Чырвоны аксамит) в физиологических условиях и при водном дефиците. В условиях прогрессирующей почвенной засухи выявлена разная динамика изменения содержания АФК и развития водного дефицита в листьях амаранта Amaranthus caudatus L. Так, через 4 сут в результате засухи зарегистрировано повышение содержания АФК в 1,58 раза относительно контроля (рис. $2, a$ ), тогда как $R W C$ практически не изменялось (см. табл. 1), а значения водного 
дефицита увеличивались на 4,7 \%, что указывает на слабое развитие водного дефицита в листьях. При усилении засухи в листьях амаранта Amaranthus caudatus L. отмечено снижение содержания АФК в 2,27 раза относительно контроля (рис. $2, b$ ) на фоне возрастания водного дефицита в 2,1 раза (табл. 2).

У растений Amaranthus paniculatus L. отмечено более сильное развитие водного дефицита в листьях уже через 4 дня почвенной засухи, чем у Amaranthus caudatus L. (см. табл. 1). Таким стрессовым условиям соответствовало уменьшение содержания АФК на $20 \%$ по сравнению с их уровнем при нормальным поливе (рис. $2, a$ ). Через 8 дней усиление действия стрессового фактора привело к росту водного дефицита в 5,2 раза по сравнению с контролем, при этом содержание АФК в листьях этого вида снизилось на $37,7 \%$ от контрольного уровня (рис. $2, b$ ). Повышение уровня АФК в листьях Amaranthus caudatus L. при умеренном водном дефиците можно рассматривать как сигнальный процесс, обеспечивающий формирование защитных реакций при недо-
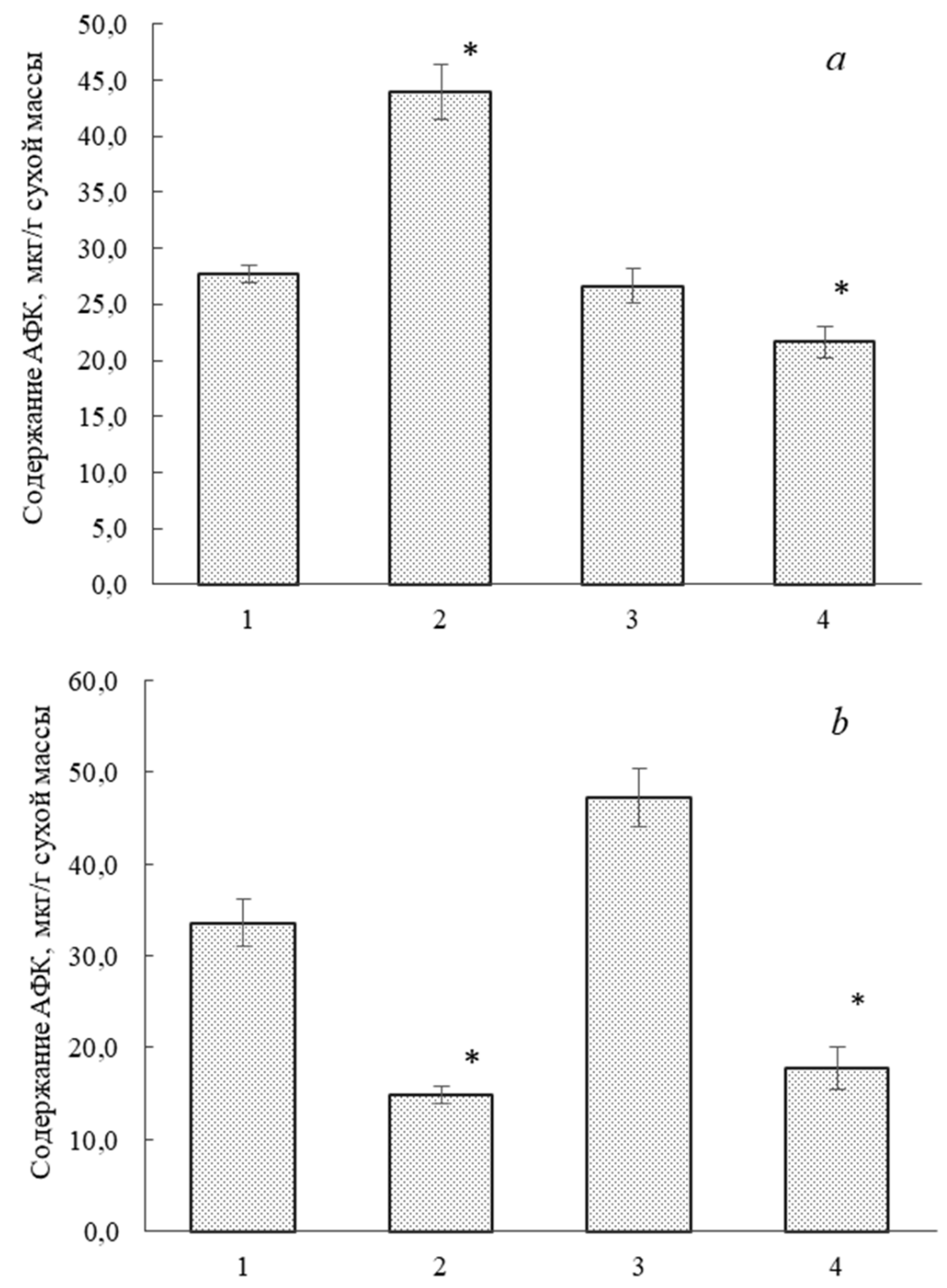

Рис. 2. Влияние 4-дневной (a) и 8-дневной (b) почвенной засухи на содержание АФК в листьях Amaranthus caudatus L., сорт Чырвоны аксамит (1 - контроль, 2 - засуха) и Amaranthus paniculatus L., сорт Рубин (3 - контроль, 4 - засуха)

Fig. 2. Effect of 4-days (a) and 8-days (b) soil drought on common content of reactive oxygen species in amaranth leaves of species Amaranthus caudatus L., Chyrvony aksamit ( 1 - control, 2 - drought) and Amaranthus paniculatus L., Rubin (3- control, 4 - drought) 
статочном водоснабжении растительных клеток [28]. Вместе с тем при возрастании давления стрессового фактора в листьях амаранта двух видов наблюдалось снижение уровня АФК относительно физиологических значений. Механизмы уменьшения продукции АФК в данном случае требуют специального исследования, однако в целом полученные данные свидетельствуют о различных механизмах генерации АФК в листьях амаранта на разных этапах почвенной засухи.

Полиненасыщенные жирные кислоты, присутствующие в мембранах растений, реагируют с АФК, что вызывает развитие процессов ПОЛ. В результате образуются высокореактивные химические соединения на основе липидов, которые могут подвергаться дальнейшему ферментативному или неферментативному разложению с образованием новых компонентов, таких как реактивные карбонильные соединения (РКС) [29]. Такие РКС способны избирательно взаимодействовать с белками, часто вызывая потерю их функциональной активности в результате реакций липоокисления. Хотя у растений существует базовая концентрация продуктов липоксидации (вероятно, участвующих в передаче сигналов), их концентрация и изменчивость возрастают экспоненциально, когда растения подвергаются биотическим/абиотическим стрессам. Такие условия обычно увеличивают присутствие АФК и экспрессию антиоксидантных ферментов вместе с РСК, а также метаболитов, возникающих в результате реакции последних с белками. Напротив, растения, обладающие определенной устойчивостью, могут демонстрировать повышенные уровни АФК и антиоксидантных ферментов, тогда как уровни маркеров окисления липидов в них, таких как МДА, обычно снижены [29].

Для характеристики активности ПОЛ в листьях амаранта в условиях засухи определяли содержание МДА, количество которого является одним из важнейших показателей засухоустойчивости растений [30]. Установлено, что динамика изменений содержания МДА в расчете на единицу сухой массы листа полностью соответствует динамике изменений содержания АФК в листьях двух видов амаранта (рис. $3, a, b$ ). Так, для Amaranthus caudatus L. зарегистрировано увеличение количества МДА в 1,6 раза после 4-дневной засухи и снижение этого показателя в 2,7 раза при возрастании водного дефицита по отношению к соответствующим контрольным значениям. В листьях Amaranthus paniculatus L. при умеренном водном дефиците наблюдалось снижение продуктов ПОЛ в 1,9 раза по сравнению с физиологическим уровнем, а при продолжении засухи количество ТБК-активных продуктов снижалось в 1,6 раза относительно соответствующих контрольных значений. Таким образом, установлено, что в условиях почвенной засухи в листьях амаранта происходит изменение состояния липидного бислоя цитоплазматических мембран, тесно связанное со степенью оводненности листьев и видовыми особенностями растений.

Следует отметить, что для выяснения причин, лежащих в основе видовых особенностей развития окислительного стресса в листьях амаранта в условиях почвенной засухи, требуется проведение специальных исследований. Исходя из имеющихся в литературе данных, можно предположить, что важным фактором, определяющим при обезвоживании характер протекания окислительных процессов в листьях амаранта двух видов, является разное содержание низкомолекулярных антиоксидантов. Известно, что низкомолекулярные фенольные соединения в листьях этих растений представлены флавоноидами, доминирующими компонентами которых являются рутин, кверцетин и трифолен [31, 32]. Листья этого рода содержат также комплекс водорастворимых витаминов: аскорбиновую кислоту, ниацин, витамины группы В. Антиоксидантное действие флавоноидных соединений обусловлено их способностью связывать свободные радикалы и образовывать соединения с ионами металлов (меди, железа), что ингибирует их каталитическое действие в процессах окисления [33]. В работе [34] при анализе водных экстрактов из стеблевых листьев двух сортов (Валентина и Early Splendor) вида Amarantus tricolor L. были обнаружены водорастворимые антиоксиданты - амарантин и аскорбиновая кислота, содержание которых у сорта Валентина было значительно выше, чем у сорта Early Splendor, в то время как у последнего отмечалось максимальное количество фотосинтезирующих пигментов. Известно, что важную роль в защите растительных клеток от окислительного стресса выполняют фотосинтетические пигменты - каротиноиды, содержание которых, по нашим данным, в листьях двух изученных видов также существенно различалось (см. рис. 1). На наш взгляд, дальнейшее 

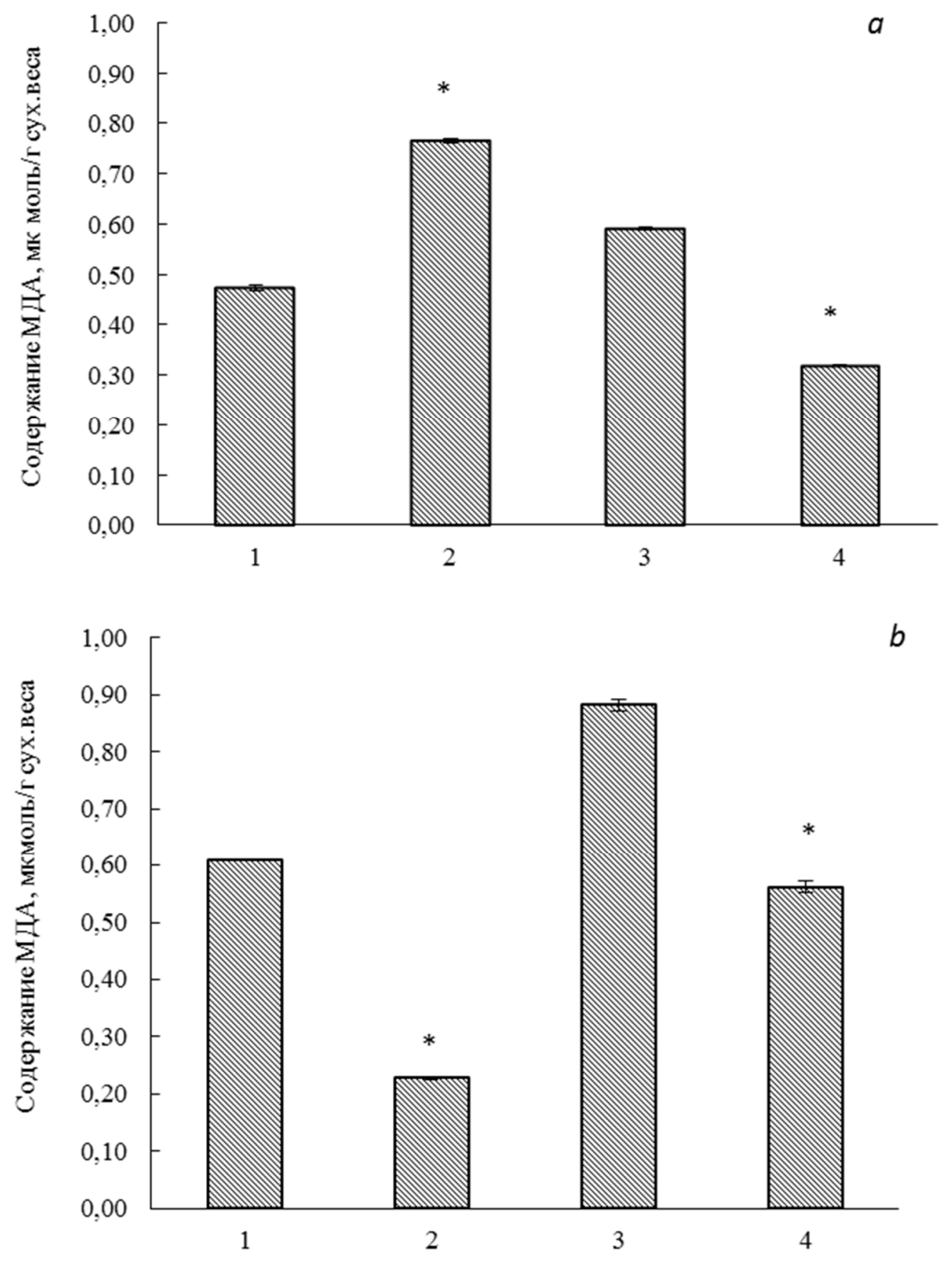

Рис. 3. Влияние 4-дневной (a) и 8-дневной (b) почвенной засухи на содержание МДА в листьях Amaranthus caudatus L., сорт Чырвоны аксамит (1 - контроль, 2 - засуха) и Amaranthus paniculatus L., сорт Рубин (3 - контроль, 4 - засуха)

Fig. 3. Effect of 4-days (a) and 8-days (b) soil drought on MDA content in amaranth leaves of species Amaranthus caudatus L.,

Chyrvony aksamit ( 1 - control, 2 - drought) and Amaranthus paniculatus L., Rubin (3 - control, 4 - drought)

изучение содержания низкомолекулярных антиоксидантов в листьях разных видов амаранта позволит установить основные причины видовых особенностей развития окислительного стресса в листьях этих растений в условиях почвенной засухи.

Заключение. Обнаружены видовые особенности развития водного дефицита в листьях амаранта в результате почвенной засухи: у растений Amaranthus paniculatus L. (сорт Рубин) уже через 4 дня недостаточного водообеспечения отмечалось более сильное развитие водного дефицита в листьях, чем у Amaranthus caudatus L. (сорт Чырвоны аксамит). После 4-дневной почвенной засухи количество фотосинтетических пигментов (Хл и каротиноидов) в пересчете на сухую массу листа увеличилось у двух видов амаранта, причем наиболее существенно у вида $\mathrm{Ama-}$ ranthus paniculatus L. (сорт Рубин). Через 8 дней в физиологических условиях наблюдалось онтогенетическое увеличение содержания фотосинтетических пигментов в листьях двух видов амаранта, причем у Amaranthus paniculatus L. более значительное, чем у Amaranthus caudatus L., но в результате засухи содержание Хл и каротиноидов в листьях двух видов амаранта снижалось практически одинаково относительно физиологического уровня. В листьях Amaranthus paniculatus L. в условиях засухи происходило существенное снижение содержания АФК и активности ПОЛ, тогда как у Amaranthus caudatus L. при умеренном водном дефиците отмечалось повышение 
этих показателей. Вместе с тем при возрастании давления стрессового фактора в листьях амаранта этих двух видов наблюдалось снижение как уровней АФК, так и активности ПОЛ относительно физиологических значений.

На основании полученных данных можно предположить, что на разных этапах почвенной засухи в листьях изученных видов амаранта имеются различия в механизмах генерации АФК и процессах ПОЛ.

Благодарности. Авторы выражают благодарность сотрудникам лаборатории биоразнообразия растительных ресурсов ГНУ «Центральный ботанический сад НАН Беларуси» С. Е. Лобану и И. М. Савич за научную консультацию и предоставленный семенной и посадочный материл двух видов амаранта - Amaranthus paniculatus L. (сорт Рубин) и Amaranthus caudatus L. (сорт Чырвоны аксамит).

Работа выполнена при финансовой поддержке Белорусского республиканского фонда фундаментальных исследований (проект № Б20Р-298) и Российского фонда фундаментальных исследований (проект № 20-516-00012).
Acknowledgements. The authors express their gratitude to the staff of the laboratory of biodiversity of plant resources of the State Scientific Institution "Central Botanical Garden of the National Academy of Sciences of Belarus" S. Ye. Loban. and I. M. Savich for scientific advice and provided seed and planting material for two species of amaranth Amaranthus paniculatus L. (Rubin variety) and Amaranthus caudatus L. (Chyrvony aksamit variety).

This work was financially supported by the Belarusian Republican Foundation for Basic Research (project No. B20R-298) and the Russian Foundation for Basic Research (project no. № 20-516-00012).

\section{Список использованных источников}

1. Urban, L. Assessing the effects of water deficit on photosynthesis using parameters derived from measurements of leaf gas exchange and of chlorophyll a fluorescence / L. Urban, J. Aarrouf, L. Bidel // Front. Plant Sci. - 2017. - Vol. 8. - Art. 2068. https://doi.org/10.3389/fpls.2017.02068

2. Variations in structural, biochemical, and physiological traits of photosynthesis and resource use efficiency in Amaranthus species (NAD-ME-type C4) / N. Tsutsumi [et al.] // Plant Product. Sci. - 2017. - Vol. 20, N 3. - P. 300-312. https://doi. org/10.1080/1343943X.2017.1320948

3. Chemical and mineral composition of amaranth (Amaranthus L.) species collected from central Malawi / N. A. Kachiguma [et al.] // J. Food Res. - 2015. - Vol. 4, N 4. - P. 92. https://doi.org/10.5539/jfr.v4n4p92

4. Таипова, Р. М. Амарант: особенности культуры, применения, перспективы возделывания в России и создания отечественных трансгенных сортов / Р. М. Таипова, Б. Р. Кулуев // Биомика. - 2015. - Т. 7, № 4. - С. $284-299$.

5. Edwards, E. J. Climate, phylogeny and the ecological distribution of C4 grasses / E. J. Edwards, Ch. J. Still // Ecol. Lett. - 2008. - Vol. 11, N 3. - P. 266-278. https://doi.org/10.1111/j.1461-0248.2007.01144.x

6. Global distribution of C3 and C4 vegetation: Carbon cycle implications / Ch. J. Still [et al.] // Global Biogeochem. Cycles. - 2003. - Vol. 17, N 1. - P. 1006. https://doi.org/10.1029/2001GB001807

7. de Carvalho, R. C. Photosynthesis by six Portuguese maize cultivars during drought stress and recovery / R. C. de Carvalho, A. Cunha, J. M. da Silva // Acta Physiol. Plant. - 2011. - Vol. 33, N 2. - P. 359-374. https://doi.org/10.1007/s11738010-0555-1

8. Photorespiration in C4 grasses remains slow under drought conditions / A. E. Carmo-Silva [et al.] // Plant, Cell \& Environment. - 2008. - Vol. 31, N 7. - P. 925-940. https://doi.org/10.1111/j.1365-3040.2008.01805.x

9. Photosynthetic responses of C3 and C4 species to seasonal water variability and competition / S. Niu [et al.] // J. Exp. Bot. - 2005. - Vol. 56, N 421. - P. 2867-2876. https://doi.org/10.1093/jxb/eri281

10. Ghannoum, O. C4 photosynthesis and water stress / O. Ghannoum // Ann. Bot. - 2009. - Vol. 103, N 4. - P. $635-644$. https://doi.org/10.1093/aob/men093

11. Sarker, U. Drought stress enhances nutritional and bioactive compounds, phenolic acids and antioxidant capacity of Amaranthus leafy vegetable / U. Sarker, S. Oba // BMC Plant Biol. - 2018. - Vol. 18, N 1. - Art. 258. https://doi.org/10.1186/ s12870-018-1484-1

12. Involvement of cytosolic ascorbate peroxidase and $\mathrm{Cu} / \mathrm{Zn}$-superoxide dismutase for improved tolerance against drought stress / M. Faize [et al.] // J. Exp. Bot. - 2011. - Vol. 62, N 8. - P. 2599-2613. https://doi.org/10.1093/jxb/erq432

13. Detecting different levels of drought stress in apple trees (Malus domestica Borkh.) with selected biochemical and physiological parameters / Šircelj H. [et al.] // Scientia Horticulturae. - 2007. - Vol. 113, N 4. - P. 362-369. http://dx.doi. org/10.1016/j.scienta.2007.04.012

14. Biochemical responses in leaves of two apple tree cultivars subjected to progressing drought / H. Šircelj [et al.] // J. Plant Physiol. - 2005. - Vol. 162, N 12. - P. 1308-1318. https://doi.org/10.1016/j.jplph.2005.01.018

15. Sarker, U. Catalase, superoxide dismutase, and ascorbate-glutathione cycle enzymes confer drought tolerance of Amaranthus tricolor / U. Sarker, S. Oba // Sci. Rep. - 2018. - Vol. 8, N 1. - Art. 16496. https://doi.org/10.1038/s41598018-34944-0

16. Variability, heritability and genetic association in vegetable amaranth (Amaranthus tricolor) / U. Sarker [et al.] // Span J. Agric. Res. - 2015. - Vol. 13, N 2. - P. e0702. https://doi.org/10.5424/sjar/2015132-6843 
17. Sarker, U. Protein, dietary fiber, minerals, antioxidant pigments and phytochemicals, and antioxidant activity in selected red morph Amaranthus leafy vegetable / U. Sarker, S. Oba // PLoS ONE. - 2019. - Vol. 14, N 12. - P. e0222517. https:// doi.org/10.1371/journal.pone.0222517

18. Sarker, U. Leaf pigmentation, its profiles and radical scavenging activity in selected Amaranthus tricolo leafy vegetables / U. Sarker, S. Oba // Sci. Rep. - 2020. - Vol. 10, N 1. - Art. 18617. https://doi.org/10.1038/s41598-020-66376-0

19. Дроздов, С. Н. Свето-температурные характеристики фотосинтеза у двух видов амаранта / С. Н. Дроздов, Е. С. Холопцева, В. В. Коломейченко // Сельскохозяйств. биология. - 2014. - № 5. - С. 96-101.

20. Вечер, Н. Н. Влияние норм высева амаранта метельчатого (Amaranthus paniculatus L.) на семенную продуктивность / Н. Н. Вечер, Т. М. Дайнеко // Глав. агроном. - 2020. - № 8. - С. 52-55.

21. Кабашникова, Л. Ф. Методы оценки физиологического состояния растений в условиях засухи : науч.-метод. пособие / Л. Ф. Кабашникова, Н. Л. Пшибытко, Л. М. Абрамчик. - Минск : Белорус. наука, 2007. - 42 с.

22. Шлык, А. А. Определение хлорофилла и каротиноидов в экстрактах зеленых листьев / А. А. Шлык // Биохимические методы в физиологии растений : сб. ст. / отв. ред. О. А. Павлинова. - М., 1971. - С. 154-170.

23. Мерзляк, М. Н. Активированный кислород и окислительные процессы в мембранах растительной клетки / М. Н. Мерзляк. - М. : ВИНИТИ, 1989. - 168 с.

24. Heath, R. L. Photoperoxidation in isolated chloroplast. 1. Kinetics and stoichicmetry of fatty acid peroxidation / R. L. Heath, L. Packer // Arch. Biochem. Biophys. - 1968. - Vol. 125, N 1. - P. 189-198. https://doi.org/10.1016/00039861(68)90654-1

25. Kozel, N. V. Barley leaf antioxidant system under photooxidative stress induced by Rose Bengal / N. V. Kozel, N. V. Shalygo // Russian. J. Plant Physiol. - 2009. - Vol. 56, N 3. - P. 316-322. https://doi.org/10.1134/S1021443709030030

26. Рокицкий, П. Ф. Биологическая статистика / П. Ф. Рокицкий. - Изд. 3-е, испр. - Минск : Вышэйш. шк., 1973. $-320 \mathrm{c}$

27. Foyer, C. H. Reactive oxygen species, oxidative signaling and the regulation of photosynthesis / C. H. Foyer // Environment. Exp. Botany. - 2018. - Vol. 154. - P. 134-142. https://doi.org/10.1016/j.envexpbot.2018.05.003

28. Cruz de Carvalho, M. H. Drought stress and reactive oxygen species: production, scavenging and signaling / M. H. Cruz de Carvalho // Plant Signal Behav. - 2008. - Vol. 3, N 3. - P. 156-165. https://doi.org/10.4161/psb.3.3.5536

29. de Dios Alché, J. A concise appraisal of lipid oxidation and lipoxidation in higher plants / J. de Dios Alché // Redox Biol. - 2019. - Vol. 23. - P. e101136. https://doi.org/10.1016/j.redox.2019.101136

30. Labudda, M. Lipid peroxidation as a biochemical marker for oxidative stress during drought. An effective tool for plant breeding [Electronic resource] / M. Labudda. - 2013. - Mode of access: http://www.e-wydawnictwo.eu/Document/ DocumentPreview/3342. - Date of access: 19.03.2021.

31. Гинс, М. С. Изменение биохимического состава листьев амаранта в результате селекции на повышенное содержания пигмента амарантина / М. С. Гинс, В. К. Гинс, П. Ф. Кононков // Прикл. биохимия и микробиология. - 2002. T. 38, № 5. - С. 556-562.

32. Хазиев, Р. Ш. Изучение биологически активных веществ растений рода Amaranthus L. : автореф. дис. ... канд. хим. наук : 03.00 .04 / Р. Ш. Хазиев ; Казан. гос. ун-т. - Казань, 1993. - 20 с.

33. Фаустова, Н. М. Комплексная фитохимическая, характеристика листьев Amaranthus cruentus (Amaranthaceae) / Н. М. Фаустова, В. М. Косман // Раст. ресурсы. - 2009. - Т. 45, вып. 4. - С. 39-53.

34. Содержание и пигментный состав автотрофной и гетеротрофной ткани листьев амаранта вида A. tricolor L. / М. С. Гинс [и др.] // Овощи России. - 2016. - № 3. - С. 79-83.

\section{References}

1. Urban L., Aarrouf J., Bidel L. Assessing the effects of water deficit on photosynthesis using parameters derived from measurements of leaf gas exchange and of chlorophyll a fluorescence. Frontiers in Plant Science, 2017, vol. 8, art. 2068. https://doi.org /10.3389/fpls.2017.02068

2. Tsutsumi N., Tohya M., Nakashima T., Ueno O. Variations in structural, biochemical, and physiological traits of photosynthesis and resource use efficiency in Amaranthus species (NAD-ME-type C4). Plant Production Science, 2017, vol. 20, no. 3, pp. 300-312. https://doi.org /10.1080/1343943X.2017.1320948

3. Kachiguma N., Mwase W., Maliro M., Damaliphetsa A. Chemical and mineral composition of amaranth (Amaranthus L.) species collected from central Malawi. Journal of Food Research, 2015, vol. 4, no. 4, p. 92. https://doi.org /10.5539/jfr. $\mathrm{v} 4 \mathrm{n} 4 \mathrm{p} 92$

4. Taipova R. M., Kuluyev B. R. Amaranth: features of culture, application, prospects of cultivation in Russia and the creation of domestic transgenic varieties. Biomika = Biomics, 2015, vol. 7, no. 4, pp. 284-299 (in Russian).

5. Edwards E. J., Still Ch. J. Climate, phylogeny and the ecological distribution of C4 grasses. Ecology Letters, 2008, vol. 11, no. 3, pp. 266-278. https://doi.org/10.1111/j.1461-0248.2007.01144.x

6. Still Ch. J., Berry J. A., Collatz G. J., DeFries R. S. Global distribution of C3 and C4 vegetation: Carbon cycle implications. Global Biogeochemical Cycles, 2003, vol. 17, no. 1, p. 1006. https://doi.org/10.1029/2001GB001807

7. De Carvalho R. C., Cunha A., da Silva J. M. Photosynthesis by six Portuguese maize cultivars during drought stress and recovery. Acta Physiologiae Plantarum, 2011, vol. 33, no. 2, pp. 359-374. https://doi.org/10.1007/s11738-010-0555-1

8. Carmo-Silva A. E., Powers S. J., Keys A. J., Arrabaça M. C., Parry M. A. J. Photorespiration in C4 grasses remains slow under drought conditions. Plant, Cell and Environment, 2008, vol. 31, no. 7, pp. 925-940. https://doi.org/10.1111/ j.13653040.2008.01805.x 
9. Niu S., Yaun Z., Zhang Y., Liu W., Zhang L., Huang J., Wan S. Photosynthetic responses of C3 and C4 species to seasonal water variability and competition. Journal of Experimental Botany, 2005, vol. 56, no. 421, pp. 2867-2876. https://doi. org/10.1093/jxb/eri281

10. Ghannoum O. C4 photosynthesis and water stress. Annals of Botany, 2009, vol. 103, no. 4, pp. 635-644. https://doi. org/10.1093/aob/men093

11. Sarker U., Oba S. Drought stress enhances nutritional and bioactive compounds, phenolic acids and antioxidant capacity of Amaranthus leafy vegetable. BMC Plant Biology, 2018, vol. 18, no. 1, art. 258. https://doi.org/10.1186/s12870-018$1484-1$

12. Faize M., Burgos L., Faize L., Piqueras A., Nicolas E., Barba-Espin G., Clemente-Moreno M. J., Alcobendas R., Artlip T., Hernandez J. A. Involvement of cytosolic ascorbate peroxidase and $\mathrm{Cu} / \mathrm{Zn}$-superoxide dismutase for improved tolerance against drought stress. Journal of Experimental Botany, 2011, vol. 62, no. 8, pp. 2599-2613. https://oi.org/10.1093/ $\mathrm{jxb} / \mathrm{erq} 432$

13. Šircelj H., Tausz M., Grill D., Franz B. Detecting different levels of drought stress in apple trees (Malus domestica Borkh.) with selected biochemical and physiological parameters. Scientia Horticulturae, 2007, vol. 113, no. 4, pp. $362-369$. http://dx.doi.org/10.1016/j.scienta.2007.04.012

14. Sircelj H., Tausz M., Grill D., Batic F. Biochemical responses in leaves of two apple tree cultivars subjected to progressing drought. Journal of Plant Physiology, 2005, vol. 162, no. 12, pp. 1308-1318. https://doi.org/10.1016/j.jplph.2005.01.018

15. Sarker U., Oba S. Catalase, superoxide dismutase, and ascorbate-glutathione cycle enzymes confer drought tolerance of Amaranthus tricolor. Scientific Reports, 2018, vol. 8, no. 1, art. 16496. https://doi.org/10.1038/s41598-018-34944-0

16. Sarker U., Islam M. T., Rabbani M. G., Oba S. Variability, heritability and genetic association in vegetable amaranth (Amaranthus tricolor). Spanish Journal of Agricultural Research, 2015, vol. 13, no. 2, p. e0702. https://doi.org/10.5424/ sjar/2015132-6843

17. Sarker U., Oba S. Protein, dietary fiber, minerals, antioxidant pigments and phytochemicals, and antioxidant activity in selected red morph Amaranthus leafy vegetable. PLoS ONE, 2019, vol. 14, no. 12, p. e0222517. https://doi.org/10.1371/journal.pone. 0222517

18. Sarker U., Oba S. Leaf pigmentation, its profiles and radical scavenging activity in selected Amaranthus tricolor leafy vegetables. Scientific Reports, 2020, vol. 10, no. 1, art. e18617. https://doi.org/10.1038/s41598-020-66376-0

19. Drozdov S. N., Kholoptseva E. S., Kolomeichenko V. V. Light-temperature characteristics of photosynthesis in two amaranth species. Sel'skokhozyaistvennaya biologiya [Agricultural biology], 2014, no. 5, pp. 96-101 (in Russian).

20. Vecher N. N., Dayneko T. M. Influence of seeding rates of amaranth paniculata (Amaranthus paniculatus L.) on seed productivity. Glavnyi agronom [Chief agronomist], 2020, no. 8, pp. 52-55 (in Russian).

21. Kabashnikova L. F., Pshibytko N. L., Abramchik L. M. Methods for assessing the physiological state of plants in drought conditions. Minsk, Beloruskaya nauka Publ., 2007. 42 p. (in Russian).

22. Shlyk A. A. Determination of chlorophyll and carotenoids in extracts of green leaves. Biokhimicheskie metody $v$ fiziologii rastenii: sbornik statei [Biochemical methods in plant physiology: collection of articles]. Moscow, 1971, pp. 154-170 (in Russian).

23. Merzlyak M. N. Activated oxygen and oxidative processes in plant cell membranes. Moscow, All-Russian Institute of Scientific and Technical Information of the Russian Academy of Sciences, 1989. 168 p. (in Russian).

24. Heath R. L., Packer L. Photoperoxidation in isolated chloroplast. 1. Kinetics and stoichicmetry of fatty acid peroxidation. Archives of Biochemistry and Biophysics, 1968, vol. 125, no. 1, pp. 189-198. https://doi.org/10.1016/00039861(68)90654-1

25. Kozel N. V., Shalygo N. V. Barley leaf antioxidant system under photooxidative stress induced by Rose Bengal. Russian Journal of Plant Physiology, 2009, vol. 56, no. 3, pp. 316-322. https://doi.org/10.1134/S1021443709030030

26. Rokitskii P. F. Biological statistics. 3rd ed. Minsk, Vysheishaya shkola Publ., 1973. 320 p. (in Russian).

27. Foyer C. H. Reactive oxygen species, oxidative signaling and the regulation of photosynthesis. Environmental and Experimental Botany, 2018, vol. 154, pp. 134-142. https://doi.org/10.1016/j.envexpbot.2018.05.003

28. Cruz de Carvalho M. H. Drought stress and reactive oxygen species: production, scavenging and signaling. Plant Signaling and Behavior, 2008, vol. 3, no. 3, pp. 156-165. https://doi.org/10.4161/psb.3.3.5536

29. De Dios Alché J. A concise appraisal of lipid oxidation and lipoxidation in higher plants. Redox Biology, 2019, vol. 23, p. e101136, https://doi.org/10.1016/j.redox.2019.101136

30. Labudda M. Lipid peroxidation as a biochemical marker for oxidative stress during drought. An effective tool for plant breeding. Available at: http://www.e-wydawnictwo.eu/Document/DocumentPreview/3342 (accessed 19.03.2021).

31. Gins M. S., Gins V. K., Kononkov P. F. Changes in the biochemical composition of amaranth leaves as a result of selection for an increased content of amarantine pigment. Prikladnaya biokhimiya i mikrobiologiya [Applied biochemistry and microbiology], 2002, vol. 38, no. 5, pp. 556-562 (in Russian).

32. Khaziev R. Sh. Study of biologically active substances of plants of the genus Amaranthus L. Abstract of Ph. D. diss. Kazan, 1993. 20 p.

33. Faustova N. M., Kosman V. M. Complex phytochemical characteristic of leaves of Amaranthus cruentus (Amaranthaceae)]. Rastitel'nye resursy [Vegetable resources], 2009, vol. 45, iss. 4, pp. 39-53 (in Russian).

34. Gins M. S., Pivovarov V. F., Gins V. K., Baikov A. A., Platonova S. Yu., Gins E. M. Content and pigment composition of autotrophic and heterotrophic tissue of amaranth leaves of A. tricolor L. Ovoshchi Rossii [Vegetables of Russia], 2016, vol. 3, pp. 79-83 (in Russian). 


\section{Информация об авторах}

Кабашникова Людмила Федоровна - член-корреспондент, д-р биол. наук, доцент, заведующий лабораторией. Институт биофизики и клеточной инженерии НАН Беларуси (ул. Академическая, 27, 220072, г. Минск, Республика Беларусь). E-mail: kabashnikova@ibp.org.by

Доманская Ирина Николаевна - канд. биол. наук, науч. сотрудник. Институт биофизики и клеточной инженерии НАН Беларуси (ул. Академическая, 27, 220072, г. Минск, Республика Беларусь). E-mail: domanin07@mail.ru

Пилипович Татьяна Сергеевна - мл. науч. сотрудник. Институт биофизики и клеточной инженерии НАН Беларуси (ул. Академическая, 27, 220072, г. Минск, Республика Беларусь. E-mail: tatsiana.bachyshch@gmail.com

Пашкевич Любовь Валерьевна - науч. сотрудник. Институт биофизики и клеточной инженерии НАН Беларуси (ул. Академическая, 27, 220072, г. Минск, Республика Беларусь). E-mail: ljubi.k87@gmail.com

Мартысюк Анна Викторовна - мл. науч. сотрудник. Институт биофизики и клеточной инженерии НАН Беларуси (ул. Академическая, 27, 220072, г. Минск, Республика Беларусь). E-mail: anya.mart@list.ru

Мотылева Светлана Михайловна - канд. с.-х. наук, доцент, заведующий лабораторией. Федеральный научный селекционно-технологический центр садоводства и питомниководства (ул. Загорьевская, 4, 115598, г. Москва, Российская Федерация). E-mail: motyleva_svetlana@mail.ru

Гинс Мурат Сабирович - член-корреспондент, д-р биол. наук, заведующий лабораторией. Федеральный научный центр овощеводства (ул. Селекционная, 14, 143080, пос. ВНИИССОК, Московская обл). E-mail: anirr@bk.ru

Тетянников Николай Валерьевич - канд. с.-х. наук, науч. сотрудник. Федеральный научный селекционнотехнологический центр садоводства и питомниководства (Загорьевская 4, 115598, г. Москва, Российская Федерация). E-mail: tetyannikovnv@ya.ru

\section{Information about the authors}

Luidmila F. Kabashnikova - Corresponding Member, D. Sc. (Biol.), Associate Professor, Head of the Laboratory. Institute of Biophysics and Cell Engineering of the National Academy of Sciences of Belarus (27, Akademicheskaya Str., 220072, Minsk, Republic of Belarus). E-mail: kabashnikova@ibp.org.by

Irina N. Domanskaya - Ph. D. (Biol.), Researcher. Institute of Biophysics and Cell Engineering of the National Academy of Sciences of Belarus (27, Akademicheskaya Str., 220072, Minsk, Republic of Belarus. E-mail: domanin07@, mail.ru

Tatsiana S. Pilipovich - Junior Researcher. Institute of Biophysics and Cell Engineering of the National Academy of Sciences of Belarus (27, Akademicheskaya Str., 220072, Minsk, Republic of Belarus). E-mail: tatsiana.bachyshch@, gmail.com

Liubou V. Pashkevich - Researcher. Institute of Biophysics and Cell Engineering of the National Academy of Sciences of Belarus (27, Akademicheskaya Str., 220072, Minsk, Republic of Belarus). E-mail: ljubi.k87@gmail.com

Hanna V. Martysiuk - Junior Researcher. Institute of Biophysics and Cell Engineering of the National Academy of Sciences of Belarus (27, Akademicheskaya Str., 220072, Minsk, Republic of Belarus). E-mail: anya.mart@list.ru

Svetlana M. Motyleva - Ph. D. (Agricult.), Associate Professor, Head of the Laboratory. Federal Horticultural Research Center for Breeding, Agrotechnology and Nursery (4, Zagorevskaya Str., 115598, Moscow, Russian Federation). E-mail: motyleva_svetlana@mail.ru

Murat S. Gins - Corresponding Member, D. Sc. (Biol.), Associate Professor, Head of the Laboratory. Federal Scientific Center of Vegetable Growing (14, Selektsionnaya Str., 143080, VNIISSOK village, Moscow region). E-mail: anirr@, bk.ru

Nikolay V. Tetyannikov - Ph. D. (Agricult.), Researcher. Federal Horticultural Research Center for Breeding, Agrotechnology and Nursery (4, Zagorevskaya Str., 115598, Moscow, Russian Federation). E-mail: tetyannikovnv@ya.ru 